\title{
SISTEM KEAMANAN BERLAPIS PADA RUANGAN MENGGUNAKAN RFID (RADIO FREQUENCY IDENTIFICATION) DAN KEYPAD UNTUK MEMBUKA PINTU SECARA OTOMATIS
}

\author{
Muhammad Chamdun $^{1)}$, Adian Fatchur Rochim ${ }^{2)}$, Eko Didik Widianto ${ }^{2)}$ \\ Jurusan Teknik Sistem Komputer, Fakultas Teknik, Universitas Diponegoro, \\ Jln. Prof. Sudharto, Tembalang, Semarang, Indonesia \\ email :m_hamdun@ymail.com
}

\begin{abstract}
This final project aims to design a door security device using RFID technology (Radio Frequency Identification) and the keypad as a method of access into the room. The system will automatically give warning when the code is entered incorrectly or burglars entered by breaking the door. The microcontroller that is used as the central data processing is ATMega 16 microcontroller ATMEL production and security sensors are used PIR (Passive Infra Red) and magnetic switches.

The design begins with a schematic device hardware and software design using CodeVisionAVR programming. Implementation phase includes the implementation of the physical tools, programs, and sensors. The testing phase is done by testing the input sensors and exit switches, siren output devices, DC motor, LCD (Liquid Crystal Display), the RFID reader, keypad, and system controller.

The results of room layered security system works according to design. PIR sensors can detect human activities and turn the LED lamp indicator on. Magnetic switch sensors will provide input to the microcontroller to enable or disable the DC motor as the room locking system. Admin menu that is accessed from the keypad is to add users, remove users, see registered users and change the password. User menu which is also accessed using the keypad, work as the room access using a username and password.

This study resulted in the layered security. Room access is done using RFIDTag and password. The room piercing detection is done by sensor PIR (Passive Infra Red) and magnetic switches. Alarm used as a piercing action warning. This layered room safety device produces a better security system.
\end{abstract}

Keywords : System Security, Microcontroller, PIR, RFID, DC Motor, Sensor

\section{Pendahuluan}

Tingkat kejahatan di Indonesia mengalami peningkatan tahun ke tahun. Jenisnya semakin beragam, ada spesialis pencuri kendaraan, pencurian toko, pencurian rumah. Teknologi untuk menghindari pencuri, misalnya pencuri rumah, maka dari itu diperlukan teknologi pengaman rumah salah satunya adalah kunci rumah itu sendiri.

Sejumlah penelitian yang bertujuan untuk membuat sebuah sistem keamanan ruangan telah banyak dikembangkan sebagai contoh, aplikasi yang telah ada ialah sistem keamanan pintu gerser menggunkan password dengan mikrokontroler, Yuniawan ${ }^{[18] .}$

Sistem tersebut belum sepenuhnya membantu seseorang dalam memonitoring keadaan rumahnya. Contoh lainya ada pembuka pintu otomatis dengan mikrokontroler dan sensor PIR, Ebizer. ${ }^{[16]}$ Aplikasi keamanan yang telah dibuat, belum ada yang mencoba mengkombinasikan atara keduanya untuk membuat sistem keamanan rumah yang lebih handal.

Penelitian ini bertujuan untuk menciptakan sebuah perangkat sistem keamanan berlapis yang mengunakan RFID (Frequency Identification), keypad, sensor keamanan PIR ( Passive Infra Red), dan magnetic switch.

Adapun beberapa tujuan dari pembuatan alat pada tugas akhir ini antara lain adalah sebagai berikut :

1. Merancang sebuah sistem keamanan rumah.

2. Mengimplementasikan hasil rancangan tersebut dalam bentuk miniatur.

3. Menguji hasil rancangan untuk sistem keamanan berlapis.

Batasan masalah pada tugas akhir ini adalah :

1. Jumlah pengaksesan masuk ruangan yang dikenali melalui RFID (Frequency Identification) dibatasi oleh memori yang tersedia pada mikrokontroler ATMega16 yaitu 100 pengguna.

2. Mikrokontroler ATMega16 sebagai pusat pengolahan data dan sistem kendali dari peralatan yang dirancang yaitu RFID (Frequency Identification), keypad, magnetic switch, LCD (Liquid Crystal Display), motor DC dan sirine.

3. LCD 16x2 digunakan untuk menampilkan karakter dari hasil program yang telah dibuat. 
4. Sensor PIR (Passive Infra Red) hanya digunakan untuk mendeteksi gerakan manusia.

5. Sensor magnetic switch digunakan untuk mengetahui pintu terbuka atau tertutup.

\section{Dasar Teori}

\subsection{RFID (Radio Frequency Indentification)}

RFID adalah proses identifikasi frekuensi gelombang radio. RFID menggunakan frekuensi radio untuk membaca informasi dari sebuah alat yang disebut RFID Tag Card.

RFID merupakan teknologi identifikasi yang fleksibel, mudah digunakan dan sangat cocok untuk oprasi otomatis. RFID mengkombinasikan keunggulan yang tidak tersedia pada teknologi identifikasi yang lain. RFID dapat disediakan dalam alat yang hanya dapat dibaca saja ( Read Only ) atau dibaca dan ditulis ( Read/Write ), tidak memerlukan kontak langsung maupun jalur cahaya untuk dapat beroprasi, dapat berfungsi pada berbagai variasi kondisi lingkungan, dan menyediakan tingkat integrasi data yang tinggi.

Secara umum RFID terdiri dari empat bagian, yaitu:

1. RFID Reader

Alat yang kompatibel dengan Tag Card RFID yang berkomunikasi secara wireless dengan Tad Card.

2. RFID Tag Card

Alat yang menyimpan informasi untuk identifikasi obyek.RFID Tag Card juga sering disebut transponder.

3. Antena

Alat untuk mentransmisikan sinyal RF antara RFID Reader dengan RFID Tag Card.

4. Software aplikasi

Untuk memproses dan menampilkan data yang dimiliki suatu RFID Tag Card yang telah dibaca oleh RFID Reader pada sebuah alat seperti misalnya sebuah LCD.

\section{$2.2 \quad$ RFID Reder ID-12}

ID-12 adalah reader yang khusus mendeteksi RFID Tag Card frekuensi $125 \mathrm{kHz}$. RFID Tag Card yang kompatibel dengan ID-12 diantaranya GK4001 dan EM4001. Kemampuan baca ID-12 sekitar $\pm 12 \mathrm{~cm}$. Bentuk fisik ID-12 yang sering dijumpai di perlihatkan pada Gambar 2.1 .

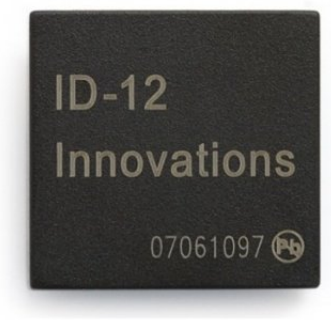

Gambar 2.1. Modul RFID ID-12

ID-12 tidak memiliki kemampuan bacatulis ( Read - Write) pada sebuah Tag Card. Format data yang dihasilkan oleh ID-12 berupa ASCII dan Wiegand26. Spesifikasi lengkap Modul RFID readerID-12 dapat dilihat pada Tabel 2.1. ${ }^{[4]}$

\subsection{RFID Tag Card}

RFID Tag Card adalah alat yang dibuat dari rangkaian elektronika dan antena yang terintergrasi didalam rangkaian tersebut. Rangkaian elektronik dari RFID Tag Card umumnya memiliki memori sehingga Tag Card ini mempunyai kemampuan untuk menyimpan data.

Berdasarkan catu daya, RFID Tag Card digolongkan menjadi:

\section{a. Tag Card Aktif}

Tag ini dapat dibaca (Read) dan ditulis (Write). Baterai yang terdapat didalam tag ini digunakan untuk memancarkan gelombang radio kepada reader sehingga reader dapat membaca data yang terdapat pada tag ini.

\section{b. Tag Card Pasif}

Tag ini hanya dapat dibaca saja (Read) dan tidak memiliki internal baterai seperti halnya tag aktif. Sumber tegangan untuk mengaktifkan tag ini didapat dari RFID reader.

\subsection{Mikrokontroler ATMega16}

Mikrokontroler adalah sebuah sistem komputer lengkap dalam satu serpih (chip). Mikrokontroler lebih dari sekedar sebuah mikroprosesor karena sudah terdapat atau berisikan ROM (Read-Only Memory), RAM (Read-Write Memory), beberapa port masukan maupun keluaran, dan beberapa peripheral seperti pencacah/pewaktu, ADC (Analog to Digital converter), DAC (Digital to Analog converter) dan serial komunikasi. 


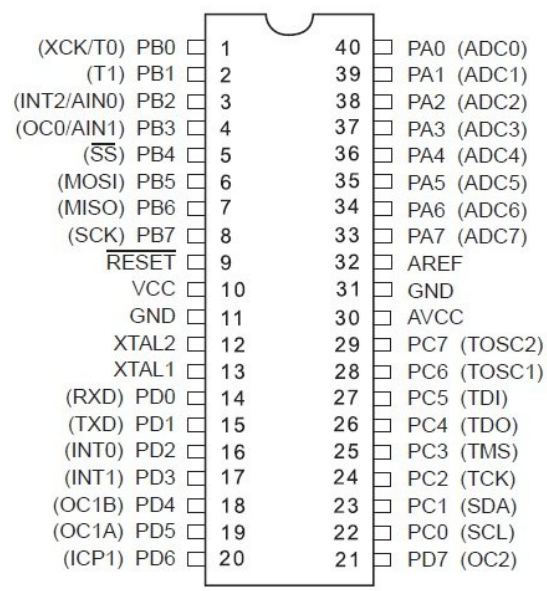

Gambar 2.10. Pena-Pena ATMega16

\subsection{Bahasa Pemrograman Mikrokontroler}

Bahasa pemrograman mikrokontroler dapat dibagi kedalam tiga kategori yaitu, bahasa tingkat rendah (bahasa mesin), bahasa tingkat menengah, dan bahasa tingkat tinggi. Mikrokontroler keluaran Atmega mampu menggunakan bahasa tingkat tinggi yang banyak dikembangkan, diantaranya adalah bahasa Basic, Bahasa C, dan bahasa Pascal. Pada rancang bangun alat ini menggunakan bahasa $\mathrm{C}$ dengan menggunakan CodeVision AVR sebagai compiler.

\subsection{Sensor}

Pengertian sensor secara umum adalah suatu peralatan yang digunakan untuk mendeteksi, mengukur atau menyimpan perubahan besaran fisika seperti panas, radiasi, perpindahan posisi dan sejenisnya untuk selanjutnya diubah menjadi informasi yang dapat di olah.

Sistem keamanan ruangan yang dirancang ini menggunakan beberapa sensor antara lain: Magnetic switch, dan PIR (Passive Infra Red) ${ }^{[14]}$

\section{a. Sensor Magnetic Switch}

Magnetic switch adalah saklar yang hubungan kontaknya sensitive terhadap medan magnet. Untuk sistem keamanan, magnetic switch digunakan sebagai sensor yang secara umum diletakan pada pintu. Satu pasang sensor terdiri dari dua buah unit, yaitu satu unit magnet bias dipasang pada pintu yang bergerak sedangkan satu unit lainya yang berisi reed kontak yang sensitive terhadap magnet diletakan pada bagian pintu yang tidak bergerak.

\section{b. Sensor PIR (Passive Infra Red)}

Sensor PIR merupakan sensor yang bekerja dengan sinyal infra red yang dipancarkan suatu obyek (dalam hal ini tubuh manusia) untuk kemudian dibandingkan dengan suhu ruangan. Sensor PIR dapat disebut Motion sensor atau Pressense Detector.

\section{Perancangan Sistem}

\subsection{Blog Diagram Rancang Sistem}

Perancangan sistem secara garis besar, dibagi menjadi lima bagian yaitu perangkat sensor input dan switch exit, perangkat output sirine dan Motor DC, LCD (Liquid Crystal Display), perangkat RFID reader dan keypad, dan sistem kontroler. Gambar 3.1, menunjukkan diagram blok perancangan sistem keamanan ruangan.

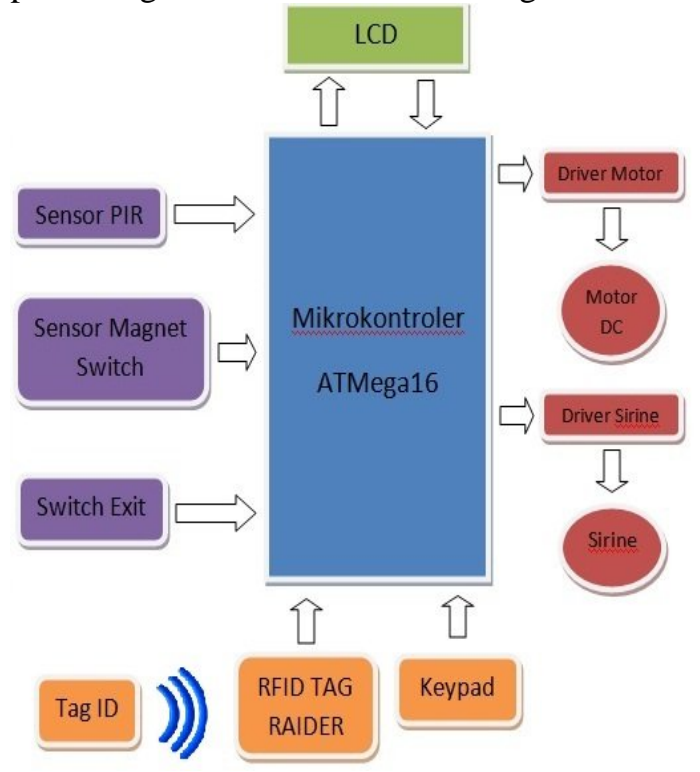

Gambar 3.1. Diagram Blok Sistem

\subsection{Perancangan Software}

Tahapan perancangan software ini, menggunakan bahasa $\mathrm{C}$ sebagai bahasa pemrograman dan CodeVisionAVR sebagai compiler pada mikrokontroler ATMega16. Tahap awal dalam perancangan software adalah membuat flowchart yang berfungsi sebagai acuan dan koreksi apabila terjadi kesalahan saat eksekusi 
program. Berikut flowchart sistem yang ditunjukan oleh Gambar 3.8.

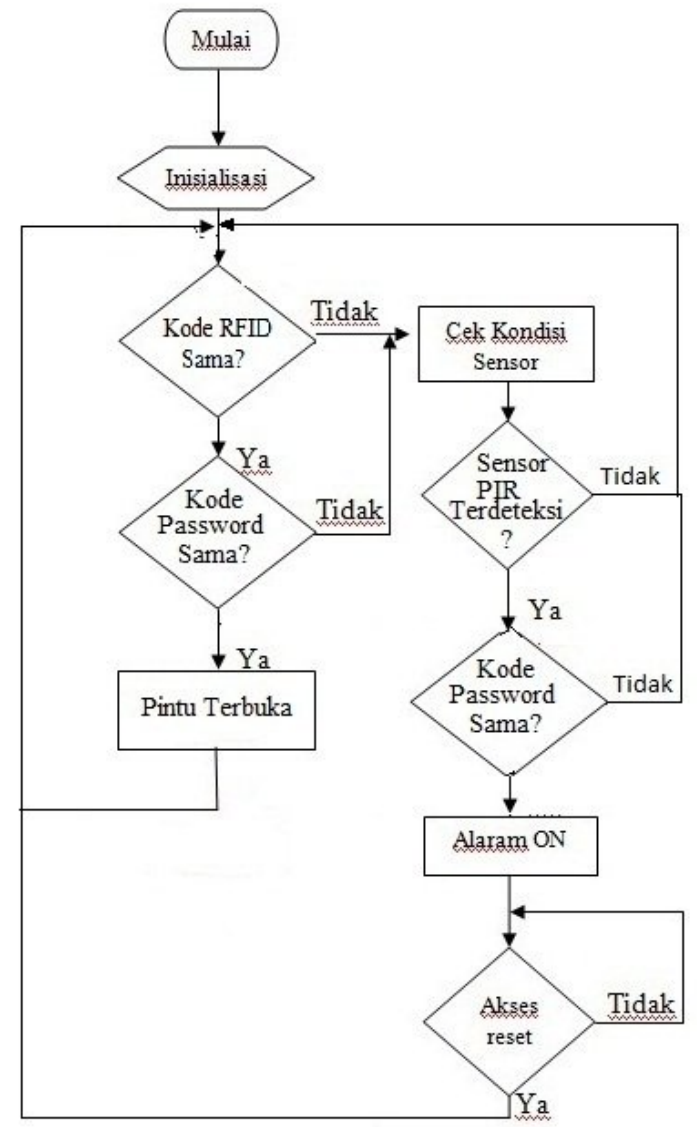

Gambar 3.8. Flowchart Sistem kerja keamanan

Proses pertama cek RFID tag, proses ini bertujuan untuk memberikan keamanan lapis pertama dimana user harus mendekatkan RFID tag yang sudah terdaftar pada sistem ke RFID reader. Jika pengecekan data sesuai dengan data pada mikrokontroler kemudian masuk proses kedua.

Proses kedua cek keypad, proses ini bertujuan untuk memberikan keamanan lapis kedua dimana user harus memasukan password yang sudah dimiliki, jika password yang dimasukan benar kunci pintu akan terbuka dan menonaktifkan sistem alarm. Ketika password yang dimasukan salah user dapat mengulagi proses ini selama tiga kali, jika password tigakali berturut-turut yang dimasukan salah sistem akan kembali pada pengecekan RFID tag.

Proses ketiga cek sensor dimana proses ini berfungsi ketika ada user yang mencoba masuk tanpa prosedur. Maka sensor keamanan akan aktif ketika pintu dibuka secara paksa.
Proses keempat akses reset dimana proses ini berfungsi sebagai mereset sistem ketika sistem sirine aktif. Proses ini bisa dilakukan terhadap user yang sudah terdaftar, untuk mematikan sistem alarm.

\section{Implementasi Alat}

\subsection{Implementasi Alat}

Implementasi sistem terdiri dari keseluruhan perangkat keras yang dirangkai untuk proses sistem keamanan ruangan. Sistem yang terdapat dalam Gambar 4.1., terdiri perangkat masukan meluputi sensor sensor passive infra red (PIR) dan sensor magnetic switch, LCD 16×2 untuk menampilkan informasi yang dikirim kontroler, motor untuk membuka kunci dan menutup kunci, Switch exit berfungri membuka pintu dari dalam ruanan, power supplay, sistem minimum, keypad dan RFID

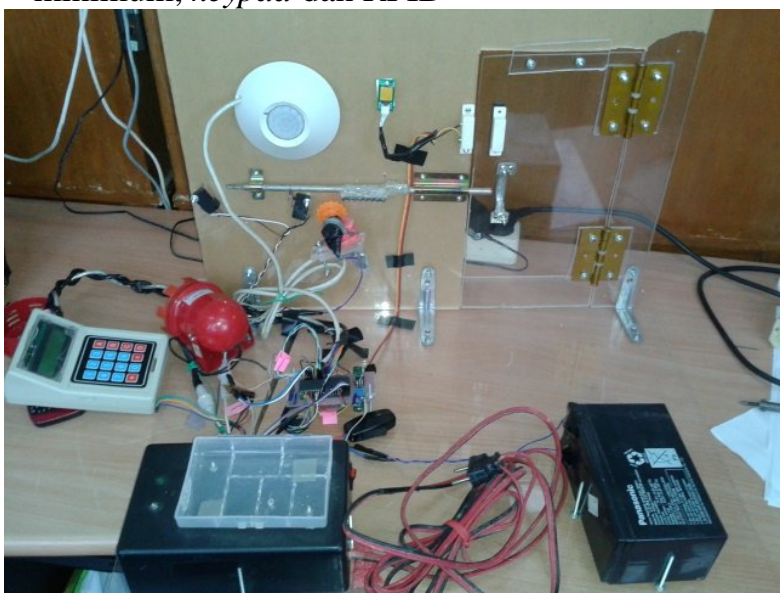

Gambar 4.1. Tampilan Keseluruhan Rangkaian Sistem Keamanan Ruangan

\section{Pengujian}

\section{$5.1 \quad 5.1 \quad$ Pengujian Subsistem LCD 16x2}

Pengujian sub sistem LCD 16x2 dilakukan dengan memprogram karakter atau tulisan yang ingin ditampilkan pada LCD dan kemudian dicocokan dengan tampilan yang ada pada layar LCD tersebut. Berikut ini adalah contoh program untuk menginisialisasi LCD :

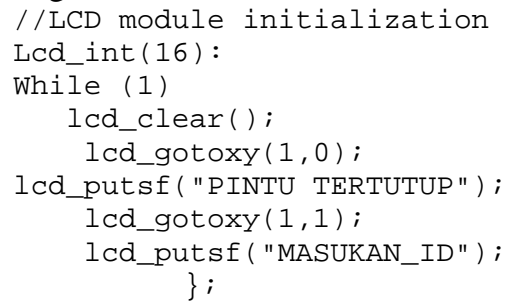


Setelah program tersebut decompile dan didownload pada mikrokontroler, maka hasil yang muncul pada LCD yang terlihat pada gambar 4.2.

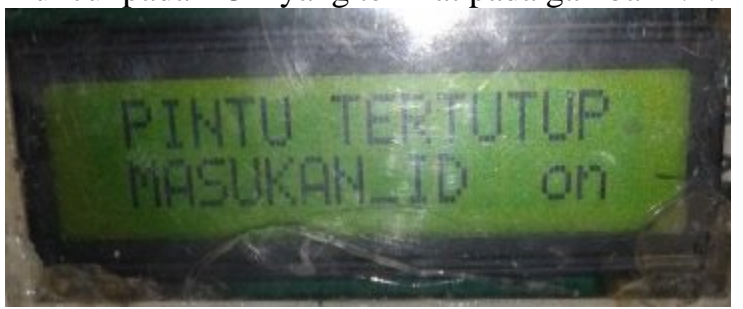

Gambar 4.2. Tampilan Awal LCD

\subsection{Pengujian Subsistem Keypad}

Pengujian subsistem keypad dengan cara member level tegangan high $(5 \mathrm{~V})$ pada sisi baris keypad dan memberikan level tegangan low (0V) pada bagian kolom keypad. Selanjutnya semua sisi baris dan kolom diberikan logika high (5V) kemudian dilakukan penekanan pada masingmasing tombol keypad secara bergantian untuk melihat keluaran logika biner dari keseluruhan pin baris dan kolom yang akan di jadikan masukan bagi mikrokontroler ATMega16. Kombinasi baris dan kolom dari tombol yang ditekan akan berlogika low $(0 \mathrm{~V})$. Tabel 4.1., dibawah ini akan di uraikan hasil pengujian logika biner dari keluaran keypad $4 \times 4$.

Tabel 4.1 Hasil Pengujian Output Keypad 4x4

\begin{tabular}{|c|c|c|c|c|c|c|c|c|}
\hline Baris & Baris & Baris & Baris & Kolom & Kolom & Kolom & Kolom & Keterangan \\
\hline 1 & $\mathbf{2}$ & $\mathbf{3}$ & $\mathbf{4}$ & $\mathbf{1}$ & $\mathbf{2}$ & $\mathbf{3}$ & $\mathbf{4}$ & \\
\hline 1 & 0 & 0 & 0 & 1 & 0 & 0 & 0 & $\mathbf{1}$ \\
\hline 1 & 0 & 0 & 0 & 0 & 1 & 0 & 0 & $\mathbf{2}$ \\
\hline 0 & 1 & 0 & 0 & 0 & 0 & 1 & 0 & $\mathbf{3}$ \\
\hline 0 & 1 & 0 & 0 & 1 & 0 & 0 & 0 & $\mathbf{4}$ \\
\hline 0 & 1 & 0 & 0 & 0 & 1 & 0 & 0 & $\mathbf{5}$ \\
\hline 0 & 0 & 1 & 0 & 1 & 0 & 0 & 0 & $\mathbf{7}$ \\
\hline 0 & 0 & 1 & 0 & 0 & 1 & 0 & 0 & $\mathbf{8}$ \\
\hline 0 & 0 & 1 & 0 & 0 & 0 & 1 & 0 & $\mathbf{9}$ \\
\hline 0 & 0 & 0 & 1 & 1 & 0 & 0 & 0 & $\mathbf{0}$ \\
\hline 0 & 0 & 0 & 1 & 0 & 1 & 0 & 0 & $*$ \\
\hline 0 & 0 & 0 & 1 & 0 & 0 & 1 & 0 & $\#$ \\
\hline 0 & 0 & 0 & 1 & 0 & 0 & 0 & 1 & $\mathbf{D}$ \\
\hline
\end{tabular}

Hasil pengujian keypad pada Tabel 4.1, terlihat setiap penekanan satu tombol dari keypad $4 \times 4$ merupakan kombinasi dari satu pin baris dan satu pin kolom, serta dari semua hasil keseluruhan logika biner yang ada, pada dasarnya tidak ada persamaan antara satu karakter dengan karakter lainya. Ini membuktikan bahwa setiap satu tombol pada keypad mewakili satu karakter yang tertera pada tombol tersebut.

\subsection{Pengujian Subsistem RFID}

Pengujian sub sistem RFID dilakukan dengan membuat program pengenalan RFID pada mikrokontroler. Data RFID tag yang akan dikenali dan dimasukan dalam database memori mikrokontroler. Pengujian sub sistem RFID bertujuan untuk mengetahui seberapa jau kemapuan jarag baca RFID reader. RFID tag yang digunakan yaitu bertipe GK4001 sebanyak tiga buah.

Indikator pendeteksi dapat diketahui dari bunyi buzzer pada rangkaian RFID. Pengujian dilakukan dari $0 \mathrm{~cm}$ sampai dengan $10 \mathrm{~cm}$. berikut ini table data pengujian jarak deteksi tag terhadap RFID reader.

Tabel 4.2 Data pengujian deteksi jarak tag ID terhadap RFID reader

\begin{tabular}{|c|c|c|c|c|}
\hline NO & $\begin{array}{c}\text { Jarak } \\
\text { Deteksi } \\
(\mathbf{c m})\end{array}$ & $\begin{array}{c}\text { Kartu } \\
\mathbf{1}\end{array}$ & $\begin{array}{c}\text { Kartu } \\
\mathbf{2}\end{array}$ & $\begin{array}{c}\text { Kartu } \\
\mathbf{3}\end{array}$ \\
\hline 1 & 1 & OK & OK & OK \\
\hline 2 & 2 & OK & OK & OK \\
\hline 3 & 3 & OK & OK & OK \\
\hline 4 & 4 & OK & OK & OK \\
\hline 5 & 5 & OK & OK & OK \\
\hline 6 & 6 & Gagal & Gagal & Gagal \\
\hline 7 & 7 & Gagal & Gagal & Gagal \\
\hline 8 & 8 & Gagal & Gagal & Gagal \\
\hline 9 & 9 & Gagal & Gagal & Gagal \\
\hline 10 & 10 & Gagal & Gagal & Gagal \\
\hline
\end{tabular}

Pengujian RFID dilakukan dengan menggunakan tiga kartu dengan serial number yang berbeda dan indikator pendeteksi diketahui dari buzzer atau tidak. Data pada tabel dapat diketahui bahwa tag ID dapat di baca oleh RFID reader sampai jarak $5 \mathrm{~cm}$.

\subsection{Pengujian Sensor PIR (Passive Infra Red)}

Pengujian sensor passive infra red (PIR) bertujuan untuk mengetahui kemampuan sensor dalam mendeteksi keberadaan manusia pada jarak sejauh enam meter dari sensor PIR, dengan cara membuat rangkaian pengujian sensor PIR seperti gambar 4.1. kemudian membuat simulasi dengan seseorang melakukan gerakan, selanjutnya mengamati menyalanya indicator LED pada sensor PIR. Jika indicator LED pada sensor PIR menyala maka menandakan kontak NC terbuka/open yang berarti resistansi kontak NC tak hingga ( ) Ohm, sedangkan jika indikator LED tidak menyala maka menandakan kontak NC tertutup/close yang berarti resistansi NC nol (0) Ohm. Percobaan ini di ulangin sebanyak 10 kali dan mencatat hasilnya pada Tabel 4.3. 
Tabel 4.3. Hasil pengujian sensor passive infra red (PIR)

\begin{tabular}{|c|c|c|}
\hline NO & Jarak Deteksi (m) & LED PIR \\
\hline 1 & 1 & ON \\
\hline 2 & 2 & ON \\
\hline 3 & 3 & ON \\
\hline 4 & 4 & ON \\
\hline 5 & 5 & OFF \\
\hline 6 & 6 & OFF \\
\hline 7 & 7 & OFF \\
\hline 8 & 8 & OFF \\
\hline 9 & 9 & OFF \\
\hline 10 & 10 & OFF \\
\hline
\end{tabular}

Hasil pengujian seperti ditunjukan pada Tabel 4.3., menunjukan bahwa pada jarak 1-4 meter, sensor PIR dapat mendeteksi obyek dengan baik dan mempunyai tegangan keluaran (Vout) sebesar 4,87 volt, sementara pada jarak 5-10 meter sensor PIR tidak dapat mendeteksi obyek. Ketika ada seseorang yang bergerak pada cakupan area sensor PIR maka kontak NC sensor PIR akan membuka/open ( resistansi nol Ohm). Perubahan resistansi pada kontak sensor PIR ini digunakan untuk men-trigger sistem kontroler yang menandakan bahwa ada seorang dalam ruangan.

\subsection{Pengujian Sensor Magnetic Switch}

Pengujian sensor magnetic switch bertujuan untuk mengetahui nilai toleransi jarak antara magnet switch yang nantinya dihubungkan sebagai masukan ke mikrokontroler ATMega16. Cara kerja magnetic switch adalah, switch akan dalam kondisi tertutup (logika'0') bila terdeteksi magnet, dan sebaliknya switch akan berada dalam kondisi terbuka (logika'1') bila tidak terdeteksi magnet. Suplai tegangan yang dibutuhkan oleh magnetic switch adalah +5VDC dan arus sebesar $100 \mathrm{~mA}$.

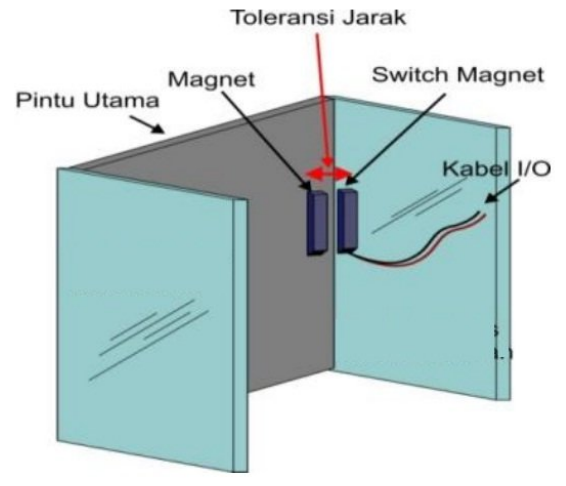

Gambar 4.3. Rangkaian pengujian sensor magnetic switch

Agar mendapatkan hasil yang baik dalam hal ini nilai logika keluaran dari magnetic switch saat pintu ditutup dan dibuka, maka perlu dilakukan pengukuran terhadap toleransi jarak antara magnet yang terpasang pada daun pintu dan switch yang terpasang pada pintu. Berikut adalah hasil pengukuran toleransi jarak magnetic switch dengan jarak pengujian $1-10 \mathrm{~cm}$ untuk mengetahui nilai keluaran tegangan dengan eksekusi output saat magnetic switch bekerja.

Tabel 4.4. Hasil Pengujian Pengukuran Sensor Magnetic Switch

\begin{tabular}{|c|c|c|c|}
\hline $\begin{array}{c}\text { Jarak } \\
(\mathbf{c m})\end{array}$ & Tegangan & Output & Logika \\
\hline 1 & 0 & ON & Rendah \\
\hline 2 & 0,24 & ON & Rendah \\
\hline 3 & 0,26 & ON & Rendah \\
\hline 4 & 0,29 & ON & Rendah \\
\hline 5 & 0,8 & ON & Rendah \\
\hline 6 & 4,24 & OFF & Tinggi \\
\hline 7 & 4,28 & OFF & Tinggi \\
\hline 8 & 4,75 & OFF & Tinggi \\
\hline 9 & 4,89 & OFF & Tinggi \\
\hline 10 & 4,97 & OFF & Tinggi \\
\hline
\end{tabular}

Hasil pengujian sensor magnetic switch pada Tabel 4.4., bahwa sensor akan berada kondisi tertutup (on) bila jarak antara magnet dan switch adalah $1-5 \mathrm{~cm}$ dengan level tegangan $0-0,8 \mathrm{~V}$, dimana untuk level tegangan seperti demikian logika yang dikeluarkan sensor sebagai masukan pada mikrokontroler akan terbaca sebagai logika ' 0 ' atau rendah. Bila jarak magnet dengan switch adalah diatas $6 \mathrm{~cm}$ yakni 7-10 $\mathrm{cm}$ dengan level tegangan 4,24-4,97V. maka posisi switch dalam keadaan terbuka (off) dan mikrokontroler akan mendeteksi masukan dari magnetic switch sebagai logika ' 1 ' atau tinggi.

Sistem keamanan ruangan pemasangan pada sensor magnetic switch dilakukan dengan jarak magnet dan switch akan diatur pada jarak pembacaan terdekat antara perpindahan logika rendah ke tinggi yaitu $5 \mathrm{~cm}$. dengan demikian jarak magnet dan switch saat pintu tertutup adalah $5 \mathrm{~cm}$. ini dilakukan agar pengoprasian pintu keamanan ruangan saat dibuka maupun ditutup akan langsung terdeteksi.

Hasil pengujian seperti yang ditunjukan pada Tabel 4.4. menjelaskan bahwa sensor magnetic switch yang digunakan dapat bekerja dengan baik. Ketika saklar/reed (yang mempunyai 
kabel) menempel dengan magnet diibaratkan seperti pintu yang kondisinya masih tertutup makan kontak NC magnetic switch masih dalam kondisi tertutup/close maka nilai resistansi $0 \mathrm{Ohm}$, sedangkan saat saklar/reed (yang tidak mempunyai kabel) menjahui magnet dengan jarak minimal dua $\mathrm{cm}$ di ibaratkan seperti pintu yang terbuka maka kontak NC magnetic switch berubah menjadi kondisi open/terbuka sehingga resistansi menjadi takhingga $(\sim \mathrm{Ohm})$. Perubahan resistansi pada sensor ini digunakan untuk men-trigger sistem kontroler.

\subsection{Pengujian Subsistem Perangkat Output}

Pengujian perangkat output adalah pengujian sirine yang digunakan dalam sistem keamanan ini. Tujuan dari pengujian adalah untuk mengetahui apakah perangkat output seperti sirine dapat bekerja dengan baik dan dapat dikendalikan oleh sistem kontrol. Dengan sumber tegangan 220VAC. Pada kondisi awal saklar SW dibuat terbuka/open, kemudian menekan saklar SW sehingga IN1 mendapat logika 1 atau tegangan +5VDC.

\subsection{Pengujian Subsistem Keseluruhan}

Berbagai Pengujian dan pengukuran yang telah dilakukan, baik secara perangkat keras (hardware) maupun perangkat lunak (software). Hasil yang didapatkan pada dasarnya telah sesuai dengan hasil perancangan. Pada perangkat input, proses pendeteksi aktifitas manusia oleh sensor PIR, fasilitas admin untuk menambah user, menghapus user, melihat user yang terdaftar dan mengganti password dengan cara masuk ke menu admin yang dikases dari keypad $4 \times 4$, dan pendeteksi pintu oleh sensor magnetic switch dapat bekerja dengan baik serta dapat memberikan masukan ke mikrokontroler untuk bisa diproses.

Selanjutnya pengujian yang dilakukan pada mikrokontroler ATMega16 dengan cara memberikan intruksi program untuk membaca setiap masukan dari komponen input, kemudian diproses dan melakukan eksekusi terhadap perangkat output telah berjalan sesuai fungsinya. Setiap port pada mikrokontroler ATMega16 yang berfungsi sebagai input maupun output dapat bekerja dengan baik.

Perangkat output,dari sisi pengujian yang dilakukan baik hardware maupun software terhadap kinerja masing-masing komponen juga mendapatkan hasil yang maksimal sesuai harapan. Eksekusi mikrokontroler ATMega16 terhada alaram sebagai komponen yang memberikan informasi berupa bunyi bila terjadi pembobolan ruangan.

Sistem pengunci pintu ruangan secara otomatis ini menggunakan montor DC berdasarkan hasil percobaan juga berjalan sesuai fungsinya. Dengan mengacu kinerja sensor magnetic switch yang akan memberikan input bagi mikrokontroler untuk mengaktifkan atau menonaktifkan motor $\mathrm{DC}$, sistem pengunci ruangan ini bekerja dengan baik.

LCD 16x2 sebagai penampil karakter melalui percobaan yang dilakukan,saat memasukan tag ID, masukan password juga berfungsi dengan baik. Fungsi admin, menambah user,melihat user, juga berfungsi dengan baik.

Berdasarkan analisa kinerja yang telah dilakukan, hasil yang didapat adalah semua komponen dapat bekerja dengan baik sesuai fungsinya. Sehingga menunjang aplikasi kinerja sistem keamanan ruangan.

\section{Penutup}

\subsection{Kesimpulan}

1. Kartu ID yang dapat digunakan untuk membuka akses keypad dan membuka pintu ruangan hanya kartu ID yang sudah terdaftar.

2. Tahap peamanan pertama yang dilakukan oleh sistem berjalan dengan baik, karena mikrokontroler dapat membandingkan data RFID Tag Card.

3. Tahap pengaman kedua yang dilakukan oleh sistem berjalan dengan baik karena dapat membandingkan empat digit password yang dimasukan melalui keypad.

4. Sistem keamanan telah diuji dengan memasang semua blok sensor kemanan seperti magnetic switch, passive infra red (PIR) yang mampu mendeteksi keberadaan penyusup, serta secara otomatis membunyikan alarm ketika ada penyusup masuk.

\subsection{Saran}

1 Pengembangan sistem keamanan ruangan ini dapat dikembangkan ke database sehingga user bisa tersimpat pada data base web bukan ke data base mikrokontroler.

2 Pengujian subsistem output sebaiknya memakai alaram yang memakai tegangan 12VDC. 


\section{DAFTAR PUSTAKA}

[1] Andrianto, Heri. 2008. Pemrograman Mikrokontroler AVR ATMEGA 16 Menggunakan Bahasa C (CodeVisionAVR)

[2] Andrianto, Heri, Pemrograman Mikrokontroler AVR ATMega16, INFORMATIKA, Bandung, 2008

[3] Budiharto, Widodo, Panduan Lengkap Belajar Mikrokontroler Perancangan Sistem dan Aplikasi Mikrokontroler, PT. Elex Media Komputindo, Jakarta, 2005.

[4] Dale R. Thompson,RFID Technical Tutorial, Departement of Computer Science and Computer Engineering, University of Arkansas, 2006.

[5] Eksa, Golda, Kriminolog UI Bagi Tips Rumah Aman Dari Aksi Pencurian, Jakarta, 2013 (metrotvnews.com)

[6] Ebiezer. 2010. Perancangan Pembuka Pintu menggunakan sensor PIR. Penulisan Ilmiah. Universitas

Gunadarma:

Jakarta

[7] Mokhammad Sholihul Hadi, Mengenal Mikrokontroller ATMega16, Ilmu komputer, 2003-2008.

[8] Nurrani,Perancangan dan Implementasi Sistem

Kehadiran Menggunakan RFID (Radio

Frequency Identification) dengan fasilitas Short Massage Servive (SMS), Skripsi Program Studi Fisika FMIPA Universitas Indonesia, 2007.

[9] Sudjadi, ST, MT., Teori dan Aplikasi Mikrokontroler, Graha Ilmu, Yogyakarta, 2005.

[10] Satrio, Irfan Aulino Budi., Detektor Emisi Gas Buang dalam Mobil dengan Dukungan Antarmuka Komunikasi Serial, Skripsi Jurusan Teknik Elektro Fakultas Teknik Universitas Diponegoro Semarang, 2006.
[11] Setiawan, Iwan ST, MT., Buku Ajar Sensor dan Tranduser. Fakultas Teknik Universitas Diponegoro, Semarang, 2009.

[12] Setiawan, Afrie, 20 Aplikasi Mikrokontroler Atmegal6 Menggunakan BASCOM AVR, Andi Offset, Yogyakarta, 2011.

[13] Supriatna, Dedi, Studi Mengenai Aspek Privasi Pada Sistem RFID, Report Institut Teknologi Bandung, Januari 2007.

[14] Woollard, Barry,Elektronika Praktis,Pradnya Pramita, Jakarta,2003.

[15] Winoto, Ardi, Mikrokontroler AVR ATMega8/32/16/8535 dengan Pemrograman bahasa C pada WinAVR, Bandung, 2008.

[16] Wardhana, L, Belajar Sendiri Mikrokontroler AVR Seri ATMega16, Simulasi Hadware dan Aplikasi, Yogyakarta, 2006.

[17] Yuniawan. Sistem keamanan pintu geser menggunakan password dengan mikrokontroler. 2008

[18] Zuhal, Dasar-dasar elektronika, PT.Gramedia Pustaka Utama, Jakarta, 1999.

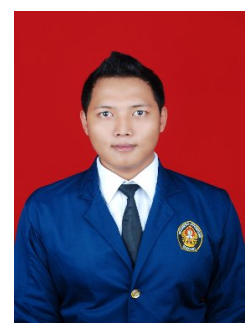

Muhammad Chamdun, lahir di Semarang, pada tanggal 24 September 1989. Memulai menempuh pendidikan di TK Pandeanlamper $\quad 01,02,03$ Semarang. kemudian di SD Pandeanlamper 04,05,06 Semarang, melanjutkan ke SMP Islam Agus Salim Semarang, dan pendidikan tingkat atas di SMK Negeri 4 Semarang. Saat ini penulis sedang menempuh pendidikan di Program Studi Sistem Komputer, Fakultas Teknik, Universitas Diponegoro, Semarang angkatan 2008. 